\section{To: (Receiving Organization): \\ Distribution \\ 5. Proj./Prog./Dept./Div.:}

300 Area stabilization Project

8. Originator Remarks:

Release of HNF-3636, Rev. 0, "Technical Basis for Characterization of B-Cell Waste for Shipment in the 3-82B Shipping Cask"

3. From: (Originating Organization)
BWHC/ 300 Area Stabilization Proj.
6. Design Authority/Design Agent/Cog. Engr.:
JG Riddelle

BWHC/300 Area Stabilization Proj.

6. Design Authority/Design Agent/Cog. Engr.:

G Riddelle

4. Related EDT No::

7. Purchase Order No.:

NA

9. Equip./Component No.

$\mathrm{NA}$

10. System/Bldg./Facility:

324 Facility

12. Major Assm. Owg. No.:

NA

13. Permit/Permit Application No:

NA

14. Required Response Date:

$11 / 18 / 98$

15.

DATA TRANSMITTED

\begin{tabular}{|l|c|}
\hline $\begin{array}{l}\text { (A) } \\
\text { tem } \\
\text { No. }\end{array}$ & (B) Document/Drawing No. \\
\hline 1 & $\mathrm{HNF}-3636$ \\
\hline & \\
\hline & \\
\hline & \\
\hline & \\
\hline & \\
\hline & \\
\hline
\end{tabular}

16.

\begin{tabular}{|c|c|l|}
\hline $\begin{array}{c}\text { (C) Sheet } \\
\text { No. }\end{array}$ & $\begin{array}{c}\text { (D) Rev. } \\
\text { No. }\end{array}$ & (E) Title or Description of Data Transmitted \\
\hline All & 0 & Technical Basis for Char.. \\
\hline
\end{tabular}

(F)

(G)

(H)

(I)

Approval Reason Origi- Receiv-

Desig- for Trans- nator er

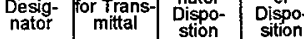

\begin{tabular}{l|l|l|l} 
nator & mittal & stion & sition \\
\hline
\end{tabular}

\begin{tabular}{|l|l|}
\hline AlI & 0 \\
\hline & \\
\hline & \\
\hline & \\
\hline & \\
\hline & \\
\hline
\end{tabular}

Reason for Transmittal (G)

4. Review

5. Post-Review

6. Dist. (Receipt Acknow. Required)

KEY

\begin{tabular}{|l|l|l|l|} 
NA & 2 & 1 & 1 \\
\hline & & & \\
\hline & & & \\
\hline & & & \\
\hline & & & \\
\hline & & & \\
\hline
\end{tabular}

\begin{tabular}{|c|l}
\hline Approval Designator (F) & \\
\hline $\begin{array}{c}\text { E, S, Q, D OR N/A } \\
\text { (See WHC-CM-3-5, }\end{array}$ & 1. Approval \\
Sec. 12.7) & 2. Release \\
\hline
\end{tabular}

17.

(See Approval Designator for required signatures)

\begin{tabular}{|c|c|c|c|c|c|c|c|c|c|}
\hline $\begin{array}{l}\text { (G) } \\
\text { Rea- } \\
\text { son }\end{array}$ & $\begin{array}{c}\text { (H) } \\
\text { Disp. }\end{array}$ & (J) Name & $\begin{array}{lll}\text { (K) Signature } & \text { (L) Date } \quad \text { (M) MSIN }\end{array}$ & $\begin{array}{l}\text { G) } \\
\text { Rea- } \\
\text { son }\end{array}$ & $\begin{array}{l}\text { (H) } \\
\text { Diso. }\end{array}$ & (J) Name & (K) Signature & (L) Date & (M) MSIN \\
\hline & & Design Authority & & 3 & & RLHILL & holliw & $11 / 28 / 98$ & $41-08$ \\
\hline & & Design Agent & & & & & & & \\
\hline & & Cog. Eng. (Same & as Cog. Mgr., below) & & & & & & \\
\hline 1 & 1 & Cog. Mgr. JG Rid & 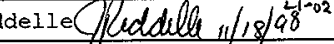 & & & & & & \\
\hline & & QA & & 3 & & Central Files & & & B] -07 \\
\hline & & Safety & & 3 & & DOE Reading Ro & $00 \mathrm{~m}$ & & $H 2-53$ \\
\hline & & Env. & & & & & & & \\
\hline orig & Sidd & $\begin{array}{l}\operatorname{lig}_{\text {IIe }} \\
\frac{11 / 18 / 98}{\text { Date }}\end{array}$ & $\begin{array}{l}\text { NA } \\
\text { Authorized Representative } \\
\text { for Recelving Organization }\end{array}$ & 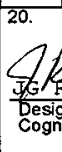 & yidd & $\frac{\text { lp }}{\text { lle }, ~} \frac{M / / g e s d}{\text { Date }}$ & $\begin{array}{r}\text { 21. DOEAP } \\
\text { Cir No. } \\
\square \text { App } \\
\square \text { App } \\
\square \text { Disa }\end{array}$ & $\begin{array}{l}\text { OVAL (if re } \\
\text { NA } \\
\text { ed } \\
\text { ed w/comm } \\
\text { roved w/cor }\end{array}$ & quired) \\
\hline
\end{tabular}




\title{
TECHNICAL BASIS FOR EXEMPTION FROM ALPHA SURVEYS FOR PERSONNEL, MATERIAL, AND EQUIPMENT IN THE 324 FACILITY
}

\author{
JS Durham \\ JSD \& Associates, Fort Collins, CO 80526 \\ Prepared for: \\ B\&W Hanford Company, Richland, WA 99352 \\ U.S. Department of Energy Contract DE-AC06-96RL13200 \\ $\begin{array}{lllll}\text { EDT/ECN: } & 625900 & \text { UC: } & 2000 & \\ \text { Org Code: } & 19300 & \text { Charge Code: } & 101031 / \text { GA00 } & \text { HN990151 } \\ \text { B\&R Code: } & \text { NA } & \text { Total Pages: } & 39.41 & \end{array}$
}

Key Words: B-Cell Waste; Alpha; Transuranic; Cesium; Strontium; Shipping Cask.

Abstract: This report documents the technical basis for the measurements and analyses used to characterize the 324 Facility grouted B-Cell waste for disposal at the Hanford Burial Grounds using the $3-82 \mathrm{~B}$ shipping cask.

TRADEMARK DISCLAIMER. Reference herein to any specific comercial product, process, or service by trade name, trademark, manufacturer, or otherwise, does not necessarily constitute or imply its endorsement, recommendation, or favoring by the United States Government or any agency thereof or its contractors or subcontractors.

Printed in the United States of America. To obtain copies of this document, contact: Document Control Services, P.0. Box 950, Mailstop H6-08, Richland WA 99352, Phone (509) 372-2420; Fax (509) 376-4989.

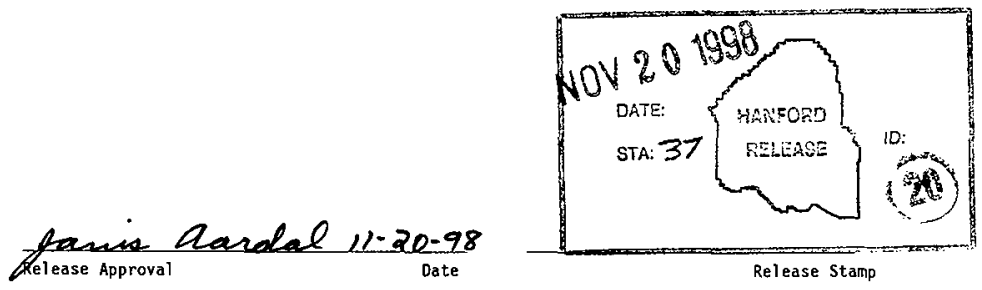

Approved for Public Release 


\section{RELEASE AUTHORIZATION}

\section{Document Number: HNF-3636, Rev. 0}

Technical Basis for Exemption from Alpha Surveys for

Document Title: Personnel, Material, and Equipment in the 324

Facility

This document, reviewed in accordance with DOE Order 241.1,

"Scientific and Technical Information Management, "and 241.1-1.

"Guide to the Management of Scientific and Technical Information," does not contain classified or sensitive unclassified information and is:

APPROVED FOR PUBLIC RELEASE

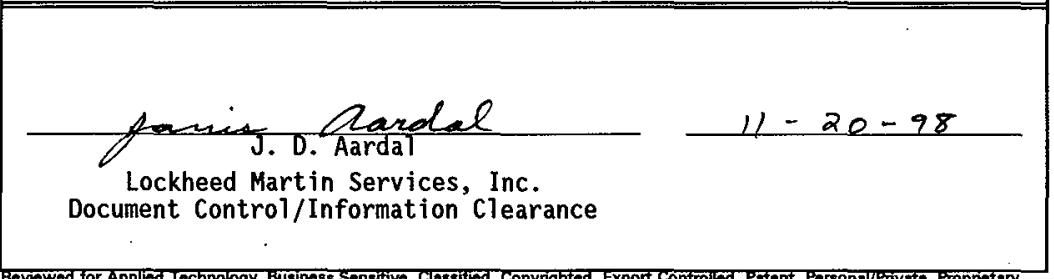
Protected CRADA, Trademark, Unclassified Controlled Nuclear intormation.

Trademark Disclaimer. Roforence horein to any specific commercial product, procese, or service by trade nama, trademark, manufecturer, or otherwise, does not necessarily constitute or imply its endorsement, recommendation, or favoring by the United States Govemment or any agency thereof or it: contractors or subcontractors. The viowe and opinions of authors expressed herein do not necesearily state or reflect thoes of the United States Govemment or any agency thereof. This report has been reproduced from the best available copy.

Printed in the United States of America.

Available to the U.S. Department of Eneryy and its contractors from the U.S. Dopartment of Enoroy Office of Scientific and Tochnical information, P.O. Box 62, Oak Ridgo, TN 37831; Tolophono: 423/576-8401.

Available to the public from the U.S. Dopartment of Commerce National Tochnical Information Sorvice, 5286 Port Royal Road. Springfield, VA 22161: Telephone: 703/487-4650. 


\section{CONTENTS}

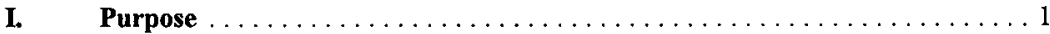

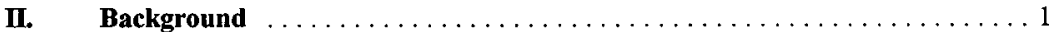

III. Applicable Limits for Disposal of B Cell Waste Packages $\ldots \ldots \ldots \ldots \ldots 3$

IV. Methodology for Determining the Radionuclide Content in a

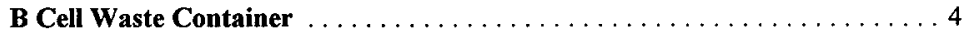

A. Dose Rate Measurements ........................ 4

B. Estimating the Cs Activity of the Grout Container $\ldots \ldots \ldots \ldots \ldots \ldots$

C. Determining ${ }^{90} \mathrm{Sr}$ and Alpha Activities $\ldots \ldots \ldots \ldots \ldots \ldots \ldots \ldots$

D. Establishing the Waste Designation . . . . . . . . . . . . . 9

E. Establishing the Heat Generation Rate $\ldots \ldots \ldots \ldots \ldots \ldots \ldots \ldots, \ldots$

F. Loading Limits for Grout Containers $\ldots \ldots \ldots \ldots \ldots \ldots \ldots \ldots$

V. Determination of the Maximum Activity of a LLW Package ......... 10

VI. Dose Rate Limits During Shipping Using the 3-82B Shipping Cask $\ldots \ldots \ldots 11$

VII. Additional Source Term Characterization $\ldots \ldots \ldots \ldots \ldots \ldots \ldots \ldots \ldots 11$

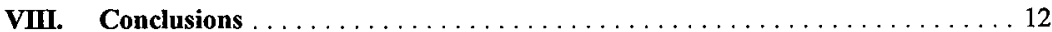

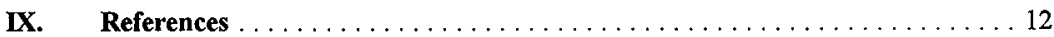

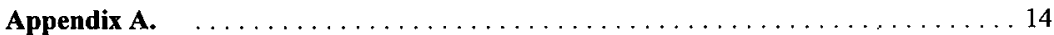

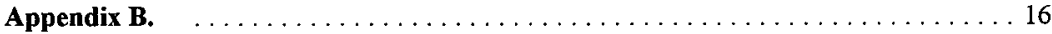

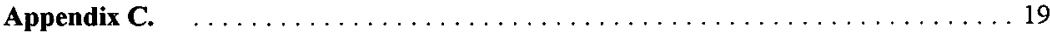

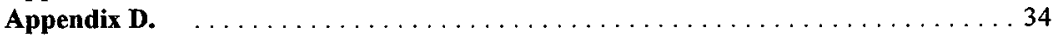

\section{FIGURES AND TABLES}

Figure 1. Linear Regression Fit of the Alpha and ${ }^{137} \mathrm{Cs}$ Activity Data $\ldots \ldots \ldots \ldots \ldots 7$

Figure 2. Linear Regression Fit of the ${ }^{90} \mathrm{Sr}$ and ${ }^{137} \mathrm{Cs}$ Activity Data for Both the 1993 and 1998 Smear Data . . . . . . . . . . . . . . . . . . . . . . . 8

Figure 3. Linear Regression Fit of the ${ }^{90} \mathrm{Sr}$ and ${ }^{137} \mathrm{Cs}$ Activity Data for the 1993 Smear Data $\ldots \ldots \ldots \ldots \ldots \ldots \ldots \ldots \ldots \ldots$

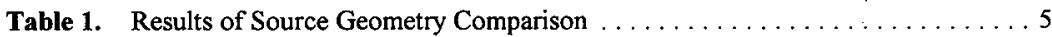

Table 2. Results of Smears ( $\mu \mathrm{Ci} /$ sample) Analyszed in 1993 and $1998 \ldots \ldots \ldots \ldots \ldots 6$

Table 3. Results of Alpha Energy Analysis for 1998 Smear Samples . . . . . . . . . . . . 9 
HNF-3636, Rev. 0

\section{TECHNICAL BASIS FOR CHARAC?CERIZATION OF B-CELLWASTE FOR SHIPMENT IN THE 3-82B SHIPPING CASK}

\section{Purpose}

The purpose of this document is to establish the technical basis for characterizing grouted B-Cell waste for disposal at the Hanford Burial Grounds using the 3-82B shipping cask. The scope of this document includes establishing the technical basis for loading the shipping package, an HN200 Grout Container, to ensure that: 1) the amourt of material in the grout container does not exceed the $100 \mathrm{nCi}$ alpha/g limit that would cause the waste to be designated as "greater that Category 3" (GC3) or transuranic (TRU) waste; 2) the amount of heat generated by the waste in the grout container does not exceed the 60 Watt heat generation limit established in the 3-82B shipping cask Safety Analysis Report (SAR); and 3) the dose rate on the surface of the shipping cask after loading does not exceed the $200 \mathrm{mrem} / \mathrm{h}$ limit established in the cask SAR. This document establishes the technical basis for performing measurements and analyses that will ensure that none of these three limits are exceeded.

\section{Background}

Historical operations between 1965 and 1992 in the 324 Facility B Cell have generated an enormous amount of legacy radioactive waste. These operations included manufacturing radioisotopic heat sources for the Federal Republic of Germany, demonstration of liquid-fed melters and spray calciners for preparation of waste packages, and dissolution of spent nuclear fuel. During these operations, millions of Curies of radioactive material, primarily ${ }^{137} \mathrm{Cs}$ and ${ }^{90} \mathrm{Sr}$ (and their related radioactive progeny, ${ }^{137} \mathrm{Ba}$ and ${ }^{9 /} \mathrm{Y}$ ), were processed in $\mathrm{B}$ Cell and some material was spilled or volatilized into the cell. No attempt. was made to clean up or completely characterize the material remaining in B Cell after each operation was concluded. Consequently, many tons of highly contaminated material in $\mathrm{B} \mathrm{Cell}$ require disposal. Millions of $\mathrm{Ci}$ of radioactive contamination, both in dispersible and fixed form, currently reside in $\mathrm{B}$ Cell.

In 1992, the US Department of Energy, the U.S. Environmental Protection Agency, and the State Of Washington Department of Ecology established a Hanford Federal Facility Agreement and Consent Order, also known as the Tri-Party Agreement (TPA). TPA milestones M-89-02, "Complete Removal of 324 Building REC B-Cell MW Equipment," scheduled for completion on $5 / 31 / 1999$, states that "actions under this milestone include containment and removal of all B Cell dispersible materials, equipment and debris" to reduce "risks to human health and the environment." In order to gain access to the dispersible material on the floor of the cell, the process racks and support equipment in B Cell must be size-reduced and placed into shipping containers, removed from the hot cell, and sent to disposal. The dispersible material on the exposed areas of the floor, which is known to contain hazardous components and has been designated as mixed waste, will be collected and placed into engineered containers. The engineered containers will be shipped to an interim storage location until a remote-handled mixed waste disposal facility is established. Cleanup activities to date have removed several racks and vessels from B-Cell and has allowed removal of dispersible mixed waste from approximately $75 \%$ 
of the floor area. The material in B Cell that must be removed to allow access to the remaining floor area consists of three equipment racks: 1-A, 1-B, and 2-A. These racks contain structural material, process piping, and tanks.

Until 1997, the waste packages containing structural material from B Cell was designated as remote-handled low-level radioactive waste (LLW). A B-Cell waste package consists of a grout container containing the waste and grout (to fill void spaces and lower the external dose rate) and a liner that reduces the amount of contamination introduced into the shipping cask from the grout container. Waste is removed from B Cell by size-reducing the racks, placing the rack material into grout containers, adding grout to the containers, loading the grout container (which becomes highly contaminated when it is introduced into B-Cell) into a liner in a relatively lowcontamination area (the REC Airlock), loading the liner into an 3-82B shipping cask, and shipping the sealed cask to the Hanford burial grounds. Designation of B Cell waste to date has relied on process knowledge and limited data on the removable contamination on the structural material.

Before shipping the waste to the Hanford burial grounds, the amount of ${ }^{137} \mathrm{Cs}$ and ${ }^{90} \mathrm{Sr}$ is determined by measuring the dose rate on the surface of the grout container (after grouting) at 24 locations ( 6 equally-spaced measurements from top to bottom at each of the four compass locations on the grout container) and determining the ${ }^{137} \mathrm{Cs}$ activity from the average of these 24 measurements using a gamma dose computer code. In the past the assumption was made that the fixed alpha contamination level of the waste was 0 . When the quantity of fixed contamination level was added to the low quantity of removable contamination that had been measured, the material would not be designated as "greater than Category 3" (GC3) or TRU waste.

The dose rates at the surface of waste packages originating from B Cell are sufficiently high that they must be handled remotely. Thus, all waste from B Cell is "remote handled." The term remote handled is not a waste designation, rather it is a descriptor that indicates how it is to be handled and stored. Throughout this document, the waste designation is independent of whether the waste packed is remote handled or contact handled.

It is important to note that designating waste as TRU or GC3 is based on the amount of alphaemitting radionuclides and the weight of the waste. There is no generic allowable quantity of alpha-emitting radionuclides for a given quantity of ${ }^{137} \mathrm{Cs}$. According to WHC-EP-0063-4, waste packages that exceed $100 \mathrm{nCi}$ of TRU radionuclides per $\mathrm{g}$ of waste are designated as TRU waste and those that exceed $100 \mathrm{nCi}$ of alpha radionuclides per $\mathrm{g}$ of waste are designated as $\mathrm{GC} 3$. In $\mathrm{B}$ Cell, approximately $15 \%$ of the alpha activity is from ${ }^{244} \mathrm{Cm}$, which is not a TRU radionuclide because the half-life of ${ }^{244} \mathrm{Cm}$ is less than 20 years. However, designation of the waste as GC3 is based on the total alpha activity; because there is no established disposal pathway for GC3 waste, B Cell waste must be less than the GC3 limit in order for the Hanford burial grounds to accept it.

In 1997, the basis for shipping B Cell waste to the Hanford burial grounds was reviewed. During the review, it was discovered that the waste designation was based on 3 smear samples from rinsed surfaces of B Cell waste in 1993. These samples were used to establish the ratio of ${ }^{90} \mathrm{Sr}$ to ${ }^{137} \mathrm{Cs}$ so that the quantity of ${ }^{90} \mathrm{Sr}$ could be determined from a gamma dose computer code 
calculation. The alpha content of waste shipped from B Cell to the Hanford burial grounds prior to 1997 was not explicitly determined. After reviewing the existing procedure for shipping waste to the burial grounds, it was decided that obtaining additional smear data was warranted.

Three additional smears were obtained for rinsed surfaces of non-waste material in B Cell in 1998. After analyzing the data, a ratio of the alpha activity to the ${ }^{137} \mathrm{Cs}$ activity was developed and shipments of waste to the Hanford burial grounds were resumed. However, a formal technical basis was never completed; a technical basis for maximizing the amount of waste in a B Cell waste package is needed to ensure that the minimum amount of resources are used without compromising safety.

This document is intended to establish the technical basis for shipping B Cell waste in HN-200 grout containers to the Hanford burial site for permanent disposal. To meet this objective, this document will include:

1) A review of the applicable requirements for shipping and waste acceptance,

2) A justification for a methodology to determine the activity of ${ }^{137} \mathrm{Cs},{ }^{90} \mathrm{Sr}$, and alphaemitting radionuclides in a grout container, the heat generation rate, and the waste designation based on measurable data,

3) A determination of the maximum activity in a B Cell waste package that can be designated as LLW,

4) A discussion of the dose rates to be encountered during shipping of LLW packages from B Cell, and

5) Recommendations for additional characterizations of the contamination in B Cell.

\section{Applicable Limits for Disposal of B Cell Waste Packages}

Limits for B Cell waste packages (grout containers) are established by the Certificate of Compliance (COC) ${ }^{1}$ and the Safety Analysis Report (SAR) ${ }^{2}$ for the 3-82B shipping cask, Department of Transportation (DOT) shipping regulations ${ }^{3}$, and Hanford solid waste acceptance criteria, WHC-EP-0063-4 $4^{4}$. The following limits are applicable to grout container waste packages:

1) The maximum alpha activity is $100 \mathrm{nCi}$ per g of waste as described in the Hanford solid waste acceptance criteria

2) The maximum heat generation rate is a grout container is 60 Watts as defined in the SAR for the 3-82B Cask 
3) The maximum dose rate of a loaded 3-82B shipping cask is $200 \mathrm{mrem} / \mathrm{h}$ at contact with the cask surface and $10 \mathrm{mrem} / \mathrm{h}$ at a distance of $2 \mathrm{~m}$ from the cask surface as required by DOT shipping regulations

The only practical method for ensuring that these limits are met for each shipment is to measure the dose rate profile at the surface of the grouted grout container, determine the Cs activity in the grout container using a computer calculation, and estimate the $\mathrm{Sr}$ and alpha activity in the grout container from the ${ }^{137} \mathrm{Cs}$ activity based on established ratios of alpha and ${ }^{90} \mathrm{Sr}$ activity to ${ }^{137} \mathrm{Cs}$ activity. The heat generation rate can then be determined from the estimated quantities of ${ }^{90} \mathrm{Sr}$ and ${ }^{137} \mathrm{Cs}$ activities. The likelihood of exceeding the shipping dose rate limit can be minimized by evaluating the results of a pre-grout dose rate profile.

\section{Methodology for Determining the Radionuclide Content in a B Cell Grout Container}

The methodology for determining the radionuclide content in a B Cell Grout Container consists of three steps:

1) Measure the surface (contact) dose rate at 24 locations around the grout container and obtain the dose rate profile

2) Estimate the ${ }^{137} \mathrm{Cs}$ content of the grout container based on the average dose rate using conversion factors computed using the computer code WISE

3) Apply measured ratios of ${ }^{90} \mathrm{Sr} /{ }^{137} \mathrm{Cs}$ and alpha $/{ }^{137} \mathrm{Cs}$ to determine the heat generation rate and to establish a waste designation.

\section{A. Dose Rate Measurements}

The dose rate in contact with the exterior of the grout container should be measured in a uniform pattern. Measurements should be made at six heights at each of four circumferential positions that correspond to the four major compass directions. From statistical purposes, 24 measurements is adequate to characterize the dose rate field around the grout container. The twenty four dose rate measurements should be added and divided by 24 to obtain the average dose rate at the surface of the grout container. An Excel spreadsheet is provided in Appendix A that, in addition to a number of other capabilities to be discussed later, calculates the average dose rate for 24 dose rate measurements for a single grout container.

\section{B. Estimating the Cs Activity of the Grout Container}

The activity of $\mathrm{Cs}$ in the grout container should be estimated using the spreadsheet provided in Appendix A. The conversion factor from $\mathrm{R} / \mathrm{h}$ to $\mathrm{Ci}$ in the Excel Spreadsheet was derived from calculations completed using the computer code WISE ${ }^{s}$. The calculated 
conversion factor from average dose to $\mathrm{Ci}$ of ${ }^{137} \mathrm{Cs}$ is $0.219 \mathrm{R} / \mathrm{h} / \mathrm{Ci}$.

WISE, which was written by Pacific Northwest National Laboratory (PNNL) for the Electric Power Research Institute (EPRI), is a shielding code that calculates the dose rate from a known source. By calculating a dose rate for a $1 \mathrm{Ci}$ source uniformly distributed throughout the interior of the grout container, a conversion factor in $\mathrm{Ci} /$ dose rate can be obtained that applies to the B Cell waste.

The HN-200 Grout Container was modeled as a right circular cylinder with an inner radius of $58 \mathrm{~cm}$, a wall thickness of $0.34 \mathrm{~cm}$, and a height of $132 \mathrm{~cm}$. The density of the grout used in B Cell is $1.6 \mathrm{~g} / \mathrm{cm}^{3}$. Dose rates were calculated in contact with the surface of the grout container. The conversion factor for a uniformly distributed source in an $\mathrm{HN}-200$ grout container is $0.219 \mathrm{R} / \mathrm{h} / \mathrm{Ci}$. Results of the calculations performed to establish the conversion factors for $\mathrm{HN}-200$ grout containers are given in Appendix B.

In order to verify the methodology for estimating the Cs activity in a grout container, the computer code WISE was used to perform a more detailed estimate of the source strength. Using WISE, the grout container was "sliced" into 6 stacked disks, which corresponds to the number of measurements taken at each compass location during a dose rate profile measurement. A different source strength was assigned to each slice of the grout container, and the dose rate profile obtained from actual measurements was modeled. Equations for the source strength in each slice were derived as a function of six dose rates that were obtained by averaging the 4 dose rates measured in contact with the surface of each slice at each major compass direction. Determining the six source strengths in terms of six dose rate measurements required solving six dependent equations containing six unknowns. The algebraic equations used to determine the six source strengths are provided in Appendix $\mathrm{C}$. In addition, the same grout container was modeled as a single homogeneous source and all 24 of the dose rate profile measurements were averaged.

The purpose of slicing the grout container into six discrete sources was to determine the sensitivity of the activity calculation to the level of complexity of the model. Table 1 shows the results of the two calculations. For the dose rate profile modeled, the difference in total ${ }^{137} \mathrm{Cs}$ activity determined using the single source method and using the six slice method was only $4.5 \%$. This exercise verifies that the method of modeling the $\mathrm{HN}-200$ grout container as a single, homogeneous source to determine the ${ }^{137} \mathrm{Cs}$ activity is valid. The results of the two calculations are provided in Appendix $\mathrm{C}$.

\begin{tabular}{|c|c|}
\hline Source Geometry & Cs Curie Content \\
\hline Single Homogeneous Source & $1133 \mathrm{Ci}$ \\
\hline 6 Independent Sources & $1186 \mathrm{Ci}$ \\
\hline
\end{tabular}

Table 1. Results of Source Geometry Comparison 
WISE uses buildup factors when calculating gamma dose. Buildup factors, if used when modeling detailed, heterogeneous sources, can lead to overestimates of calculated radiation doses because buildup is the greatest in homogeneous sources and is reduced in heterogeneous sources. When shielding codes are used to determine source strengths from dose rates, buildup factors can underestimate calculated source strengths. However, in this application the source is modeled as homogeneous and the effect of the buildup factor is appropriately modeled.

\section{Determining ${ }^{90} \mathrm{Sr}$ and Alpha Activities}

${ }^{90} \mathrm{Sr}$ and alpha activities are determined from measured ratios of ${ }^{90} \mathrm{Sr}$ activity to ${ }^{137} \mathrm{Cs}$ activity and alpha activity to ${ }^{137} \mathrm{Cs}$ activity. The ${ }^{137} \mathrm{Cs}$ activity determined based on the WISE calculations is multiplied by the two ratios to obtain the ${ }^{90} \mathrm{Sr}$ and alpha activities, respectively. The ${ }^{137} \mathrm{Cs}$ and ${ }^{90} \mathrm{Sr}$ activities are used to compute the heat generation rate and the alpha activity, divided by the weight of the grouted container, is used to designate the waste as either GC3, TRU, or LLW. It is the goal of the B Cell Cleanout Safety Project to load the grout containers so that they meet the LLW designation.

Waste material that is loaded into grout containers is rinsed prior to loading the container. Limited data exist on the ${ }^{90} \mathrm{Sr}$ and alpha activity to ${ }^{137} \mathrm{Cs}$ activity ratios for rinsed waste material. The only existing data of this type was obtained in 1993 and is shown in Table 2. The analytical counting laboratory report for these smears is included in Appendix D.

As stated in the introduction, additional smears were obtained in 1998 . However, the 1998 smears were obtained from rinsed surfaces of non-waste material and not from surfaces of waste material. Although these smears are not representative of smears obtained from rinsed waste material surfaces, the data are indicative of the B Cell environment and may be useful in developing the activity ratios. The smear data from the 1998 smears are also shown in Table 2 . The analytical data laboratory reports associated with the data in Table 2 are provided in Appendix D.

\begin{tabular}{|c|c|c|c|c|c|}
\hline Sample & $\underline{\mathrm{Cs}}$ & Alpha & $\underline{\mathrm{Sr}}$ & Alpha/Cs & $\underline{\mathrm{S} r / \mathrm{CS}}$ \\
\hline 1993-1 & 0.135 & $5.92 \mathrm{E}-05$ & $0 . \overline{365}$ & 0.000439 & 2.70 \\
\hline 1993-2 & 0.0505 & 2.29E-05 & 0.113 & 0.000453 & 2.24 \\
\hline \multirow[t]{2}{*}{ 1993-3 } & 0.0437 & $2.22 \mathrm{E}-05$ & 0.074 & 0.000508 & 1.69 \\
\hline & & & 1993 Average & 0.000467 & 2.21 \\
\hline 1998-1 & 0.00973 & $5.45 \mathrm{E}-5$ & 0.00128 & 0.00560 & 0.132 \\
\hline $1998-2$ & 0.229 & $1.00 \mathrm{E}-4$ & 0.0769 & 0.000437 & 0.336 \\
\hline \multirow[t]{2}{*}{ 1998-3 } & 8.93 & $3.65 \mathrm{E}-3$ & 0.622 & 0.000409 & 0.0697 \\
\hline & & & 1998 Average & 0.00215 & 0.179 \\
\hline
\end{tabular}

Table 2. Results of Smears ( $\mu \mathrm{Ci} /$ sample) Analyzed in 1993 and 1998. Note: The averages shown in the table are not weighted. 
Because of the similarity of the ratio of alpha activity to ${ }^{137} \mathrm{Cs}$ activity in Table 2 from both 1993 and 1998, a ratio of alpha activity to ${ }^{137} \mathrm{Cs}$ activity based on these data can be established. To establish the ratio, a plot of the alpha activity as a function of ${ }^{137} \mathrm{Cs}$ activity can be made and linear regression used to determine the slope of the line. The slope of the line, by definition, is the ratio of alpha activity to ${ }^{137} \mathrm{Cs}$ activity. The data in Table 2 are plotted in Figure 1, which also shows the results of the linear regression and the correlation coefficient. The nearness of the correlation coefficient $\left(R^{2}=0.9998\right)$ to 1 indicates a very high level of confidence associated with the regression. Note that the regression was forced through the point $(0,0)$. The linear regression was performed using functions included with Microsoft Excel ${ }^{6}$. Based on a linear regression of the data for alpha and ${ }^{137} \mathrm{Cs}$ in Table 2, the ratio of alpha activity to ${ }^{137} \mathrm{Cs}$ activity is 0.000408 .

The data in Table 2 for the ratio of ${ }^{90} \mathrm{Sr}$ activity to ${ }^{137} \mathrm{Cs}$ activity are not consistent because in the 1993 data the ratio of ${ }^{90} \mathrm{Sr}$ activity to ${ }^{137} \mathrm{Cs}$ activity is greater than 1 , while in the 1998 data the ratio is less than 1. A linear regression of both the 1993 and 1998 data is plotted in Figure 2. The correlation coefficient $\left(\mathrm{R}^{2}\right)$ of 0.4800 indicates an unacceptably low confidence in the fitted curve. Because the 1998 data results in a higher predicted ${ }^{90} \mathrm{Sr}$ activity, which leads to a conservative estimate of the heat generation rate in the waste package, the data from 1993 was used in a regression analysis to determine the ratio of ${ }^{90} \mathrm{Sr}$ activity to ${ }^{137} \mathrm{Cs}$ activity. This regression is shown in Figure 3 and the correlation coefficient, although not indicating a very high degree of confidence, is adequate for the available data. Based on the analysis, the ratio of ${ }^{90} \mathrm{Sr}$ activity to ${ }^{137} \mathrm{Cs}$ activity to be used for B Cell waste should be 2.57. Additional studies are warranted to verify and refine this ratio, however.

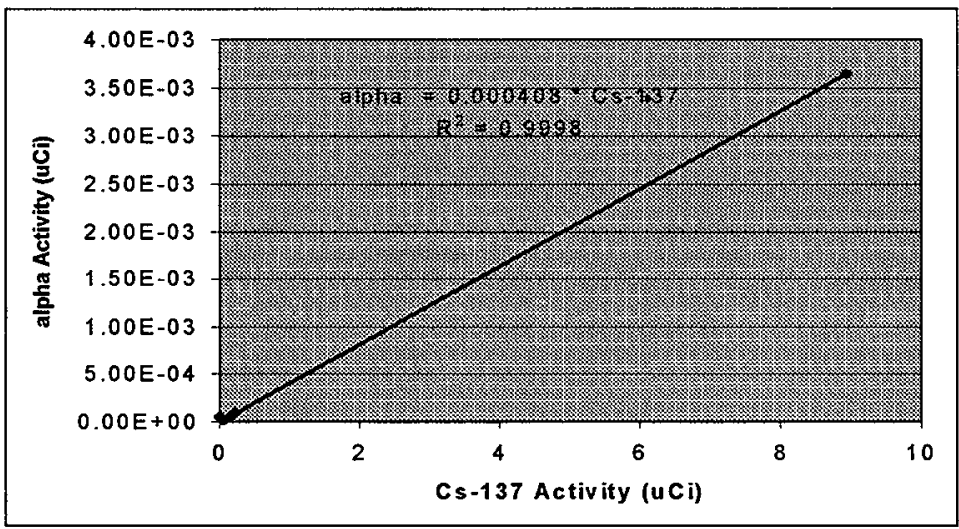

Figure 1. Linear Regression Fit of the alpha and ${ }^{137} \mathrm{Cs}$ activity data. 


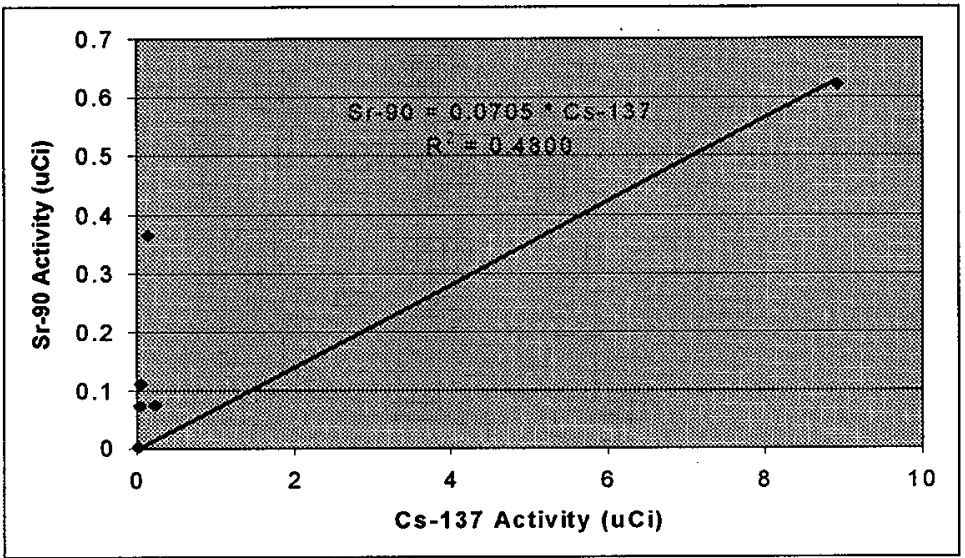

Figure 2. Linear Regression Fit of the ${ }^{90} \mathrm{Sr}$ and ${ }^{137} \mathrm{Cs}$ activity data for both the 1993 and 1998 smear data.

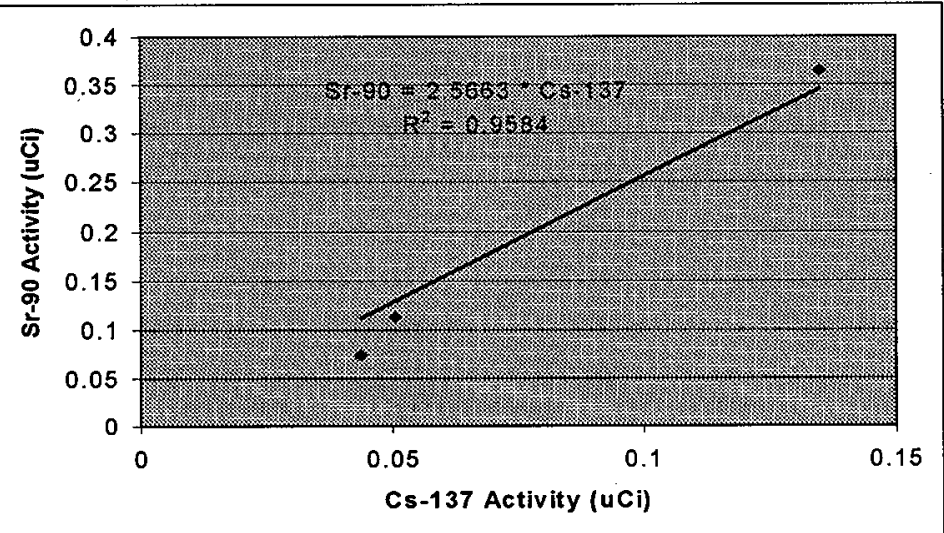

Figure 3. Linear Regression Fit of the ${ }^{90} \mathrm{Sr}$ and ${ }^{137} \mathrm{Cs}$ activity data for the 1993 smear data. 


\section{Establishing the Waste Designation}

The waste designation is established by determining the activity per gram of alpha-emitting radionuclides. This is accomplished by multiplying the calculated ${ }^{137} \mathrm{Cs}$ activity by the ratio of alpha activity to ${ }^{137} \mathrm{Cs}$ activity and dividing by the weight of the grouted container. If this value is greater than $100 \mathrm{nCi} / \mathrm{g}$, then the waste is designated as GC3. In B Cell, the only non-TRU radioisotope is ${ }^{244} \mathrm{Cm}$, which has a half life of less than 20 years. Alpha energy analysis of the smears obtain in 1998, the results of which are tabulated in Table 3, indicate that $26 \%$ of the alpha activity in B Cell is from ${ }^{244} \mathrm{Cm}$. The contributions from other alpha-emitting radionuclides are as shown in the analytical counting laboratory report in Appendix D. Therefore, if the activity per gram of alpha-emitting radionuclides is greater than $135 \mathrm{nCi} / \mathrm{g}$, then the waste is designated as TRU waste. The calculation of alpha activity per gram, and thus the designation of the waste type, is performed in the Excel spreadsheet in Appendix A.

$\begin{array}{lrrrr} & \text { Total Alpha } & { }^{244} \mathrm{Cm} & \text { Fraction Non-TRU } & { }^{137} \mathrm{Cs} \\ \text { Sample } & & & & \\ 1998-1 & 5.45 \mathrm{E}-5 & 1.21 \mathrm{E}-5 & 2.22 \mathrm{E}-1 & 9.73 \mathrm{E}-3 \\ 1998-2 & 1.00 \mathrm{E}-4 & 4.12 \mathrm{E}-5 & 4.12 \mathrm{E}-1 & 2.29 \mathrm{E}-1 \\ 1998-3 & 3.65 \mathrm{E}-3 & 5.72 \mathrm{E}-4 & 1.57 \mathrm{E}-1 & 8.93 \mathrm{E}+0 \\ \text { Average } & & & 2.63 \mathrm{E}-1 & \end{array}$

Table 3. Results of Alpha Energy Analysis for 1998 Smear Samples

It should be noted that the value determined in the Excel spreadsheet can be directly compared to the $100 \mathrm{nCi} / \mathrm{g}$ limit. Whenever measurements are made and compared to a limit, there are four possible outcomes of the comparison, two of which are "good" and two of which are "bad." The two good outcomes is that the measurement is correct, that is, when the dose rate profile indicates that the waste is non-TRU and it is actually nonTRU (true negative) and when the measurement indicates that the waste is TRU and it is actually TRU (true positive). Problems arise when the dose rate measurement indicates that the waste is non-TRU when it is actually TRU (false negative) and when the measurement indicates that the waste is TRU when it is actually non-TRU. When comparing any measurement to an established limit, all four of these outcomes are always possible, and the possibility increases when the measurements are within $20 \%$ of the limits. It is common to establish confidence intervals that change the probability of either a false positive or a false negative; however, decreasing one form of error necessarily increases the other form of error proportionally. In other words, decreasing the probability of a false negative by $50 \%$ necessarily increases the probability of a false positive by $50 \%$.

At first thought, it may seem that a false negative result is worse than a false positive result. However, one must balance the cost and risk associated with each outcome for the situation to which it is applied. A false negative outcome results in the disposal of waste containing a slightly elevated quantity of TRU radionuclides. A false positive outcome results in the generation of a waste package for which no final disposal pathway exists. 
Given the size of the waste package (roughly $1.4 \mathrm{~m}^{3}$ ) and the low activity of the transuranic radionuclides $(0.272 \mathrm{Ci}$ [see calculation below]), the risk of a slightly elevated activity of TRU radionuclides appears to be no more than equivalent to the incremental cost of storing, retrieving, and potentially repackaging the waste once a disposal pathway has been identified. Therefore, it is recommended that the measurements of alpha activity be directly compared to the limit for TRU waste without adding the value associated with a confidence interval to the measurement.

\section{E. Establishing the Heat Generation Rate}

The heat generation rate for a grouted container is based on the ${ }^{90} \mathrm{Sr}$ and ${ }^{137} \mathrm{Cs}$ activities. ${ }^{90} \mathrm{Sr}$ has a heat generation rate of $0.0067 \mathrm{~W} / \mathrm{Ci}{ }^{90} \mathrm{Sr}$ and ${ }^{137} \mathrm{Cs}$ has a heat generation rate of $0.0048 \mathrm{~W} / \mathrm{Ci}^{137} \mathrm{Cs}^{7}$. The heat generation rate is calculated in the Excel spreadsheet in Appendix A.

\section{F. Loading Limits for Grout Containers}

The heat generation rates and the ratio of ${ }^{90} \mathrm{Sr}$ activity to ${ }^{137} \mathrm{Cs}$ activity can be used to establish a maximum activity loading for a $\mathrm{B}$ Cell grout container. The maximum heat generation rate for a grout container is $60 \mathrm{~W}(205 \mathrm{BTU})^{2}$. Based on this limit, the maximum activities of the waste are $2725 . \mathrm{Ci}^{137} \mathrm{Cs}$ and $7003 \mathrm{Ci}{ }^{90} \mathrm{Sr}$. The activity of alphaemitting radionuclides associated with $2725 \mathrm{Ci}^{137} \mathrm{Cs}$ is $1.11 \mathrm{Ci}$, and the weight of a typical grout container is $2,600 \mathrm{~kg}(5,700 \mathrm{lb})$. In this case the specific alpha activity is $427 \mathrm{nCi} / \mathrm{g}$ and the waste would be designated as remote-handled TRU. Thus, at the maximum heat generation rate of the grout container, the associated quantity of alpha-emitting radionuclides would require that the waste package be designated as TRU. Therefore, the heat generation rate of any waste package that is designated as LLW will be significantly lower than the limit of $60 \mathrm{~W}$.

Note that in the previous discussion the weight of the grout container was assumed to be $2,600 \mathrm{~kg}(5,700 \mathrm{lb})$. If the actual weight is greater, more activity may be placed into the grout container. If the weight of the grouted container is less, however, the limit is more restrictive. In either case, it is not conceivable that the heat generation limit would be exceeded for a waste package that is designated as LLW using the data included in this report.

\section{Determination of the Maximum Activity of a LLW Package}

The maximum activity of alpha-emitting radionuclides in a waste package that is designated as $\mathrm{LLW}$ can be determined from the $100 \mathrm{nCi} / \mathrm{g}$ alpha activity limit, the weight of a typical waste package $(6,000 \mathrm{lb}[2720 \mathrm{~kg}])$, the ratio of alpha activity to ${ }^{137} \mathrm{Cs}$ activity (0.000408), and the ratio of ${ }^{90} \mathrm{Sr}$ activity to ${ }^{137} \mathrm{Cs}$ activity (2.57). The maximum alpha activity of a $2720 \mathrm{~kg} \mathrm{LLW}$ package is $100 \mathrm{nCi} / \mathrm{g} * 2720 \mathrm{~kg}=0.272 \mathrm{Ci}$. The ${ }^{137} \mathrm{Cs}$ activity associated with this alpha activity is $0.272 \mathrm{Ci} / .000408=667 \mathrm{Ci}^{137} \mathrm{Cs}$. The ${ }^{90} \mathrm{Sr}$ activity for 
this package is $667 * 2.57=1713 \mathrm{Ci}^{90} \mathrm{Sr}$.

The heat generation rate for this waste package, based on a ${ }^{90} \mathrm{Sr}$ heat generation rate of $0.0067 \mathrm{~W} / \mathrm{Ci}^{90} \mathrm{Sr}$ and a ${ }^{137} \mathrm{Cs}$ heat generation rate of $0.0048 \mathrm{~W} / \mathrm{Ci}^{137} \mathrm{Cs}^{4}$, is $667 * 0.0048$ $+1713 * 0.0067=14.7 \mathrm{~W}$. Thus, the heat generation rate is less than the limit of $60 \mathrm{~W}$.

VI Dose Rate Limits During Shipping Using the 3-82B Shipping Cask

Calculations of the quantity of ${ }^{137} \mathrm{Cs}$ that could be loaded into a grout container, based on the external dose rate of a loaded 3-82B shipping cask, have been previously determined ${ }^{8}$ for a ${ }^{90} \mathrm{Sr}$ activity to ${ }^{137} \mathrm{Cs}$ activity of 2.1 . The report concluded "The $3-82 \mathrm{~B}$ cask will meet the transportation dose rate limits of $0.002 \mathrm{~Sv} / \mathrm{h}(200 \mathrm{mrem} / \mathrm{h})$ on the cask surface, and $0.0001 \mathrm{~Sv} / \mathrm{h}(10 \mathrm{mrem} / \mathrm{h})$ at $2 \mathrm{~m}$ from cask surface for a mixture containing $3600 \mathrm{Ci}$ of ${ }^{137} \mathrm{Cs}$ and $7560 \mathrm{Ci}$ of ${ }^{90} \mathrm{Sr}$. The limits will be met for a radioactive source that is uniformly distributed throughout the grout container as well as a concentrated radioactive source located near the periphery of the grout container." Based on the ratio established in this document, a mixture containing $3600 \mathrm{Ci}$ of ${ }^{137} \mathrm{Cs}$ and $9252 \mathrm{Ci}^{90} \mathrm{Sr}$ would not exceed the shipping dose rate limits. $\mathrm{A}^{137} \mathrm{Cs}$ activity of $667 \mathrm{Ci}$, which is the maximum ${ }^{137} \mathrm{Cs}$ activity allowed for the B Cell waste to be designated as LLW, is well below the activity of ${ }^{137} \mathrm{Cs}$ that will cause the dose rate to exceed $200 \mathrm{mR} / \mathrm{h}$ at contact or $10 \mathrm{mR} / \mathrm{h}$ at a distance of $2 \mathrm{~m}$. Because the dose rate for shipping cannot be exceeded for a B Cell LLW package, it can be concluded that the limiting parameter for loading LLW packages is the activity of alpha-emitting radionuclides.

Should further analysis of the B Cell environment indicate that the alpha to ${ }^{137} \mathrm{Cs}$ ratio is significantly lower than the data in this document indicates, it is possible that a different constraint would exist on the activity of a waste package. The heat generation rate for a grout container loaded with the maximum activity that can still be below the shipping dose rate limit, $3600 \mathrm{Ci}$ of ${ }^{137} \mathrm{Cs}$ and $9252 \mathrm{Ci}^{90} \mathrm{Sr}$, would have a heat generation rate of $3600 * 0.0048+9252 * 0.0067=79 \mathrm{~W}$, which is greater than the heat generation rate established by the $3-82 \mathrm{~B} \mathrm{COC}$. The maximum activity of a loaded grout container that will not exceed the heat generation rate limit is $2725 \mathrm{Ci}$ of ${ }^{137} \mathrm{Cs}$ and $7003 \mathrm{Ci}^{90} \mathrm{Sr}$. If further analysis of the B Cell environment reduces the ratio of ${ }^{90} \mathrm{Sr}$ activity to ${ }^{137} \mathrm{Cs}$ activity, then the allowed activity of ${ }^{137} \mathrm{Cs}$ and ${ }^{90} \mathrm{Sr}$ would increase. In fact, if the ratio were to drop to below 1.77 , then the heat generation rate would no longer limit the activity and the shipping dose rate would be the limiting factor, providing the alpha contamination level is negligible.

\section{Additional Source Term Characterization}

Characterization of the source term in B Cell is necessary to resolve the discrepancy in the ratio of ${ }^{90} \mathrm{Sr}$ activity to ${ }^{137} \mathrm{Cs}$ activity between the 1993 smear data and the 1998 smear data. Should this ratio change significantly, the maximum cask loading could be increased if the alpha contamination issue is resolved. One method of resolving this issue is to 
pursue additional characterization of the ratio of alpha activity to ${ }^{137} \mathrm{Cs}$ activity in B Cell. Another method is to investigate methods of removing the contamination from the waste material using a nonhazardous decontamination foam or soap before introducing it into the grout container. This would reduce the ${ }^{137} \mathrm{Cs}$ and alpha activity in the waste package while increasing the amount of waste material in the container. The removed activity could then be collected with the dispersible contamination on the B Cell floor.

\section{Conclusions}

This document has established the technical basis for performing dose rate profile measurements and, based on the results of these measurements, has established the maximum activity loading of a grout container that will allow the waste package to be accepted at the Hanford burial grounds as remote-handled low level waste. In addition, this document provides the technical basis for determining the isotopic activity, the heat generation rate, and the waste designation of the waste package. The limit that currently restricts the activity that can be shipped to the Hanford burial grounds is the $100 \mathrm{nCi}$ alpha activity per gram of waste. Because of this limit, the maximum activity that can be grouted in an $\mathrm{HN}-200$ Grout Container is $667 \mathrm{Ci}^{137} \mathrm{Cs}$ based on a waste package weight of $2,720 \mathrm{~kg}(6,000 \mathrm{lb})$. For grouted HN-200 Grout Containers that weigh more than $2,720 \mathrm{~kg}$, the activity is greater; for grout containers that weigh less, the activity will be less. Regardless of the weight of the container, the heat generation rate of the contents will not exceed the SAR for the cask nor DOT shipping regulations provided that the waste package can be designated as LLW. The ratio of alpha activity to ${ }^{137} \mathrm{Cs}$ activity should be 0.000408 , and the ratio of ${ }^{90} \mathrm{Sr}$ activity to ${ }^{137} \mathrm{Cs}$ activity should be 2.57 . The conversion from average dose rate to ${ }^{137} \mathrm{Cs}$ activity should be $0.219 \mathrm{R} / \mathrm{h} / \mathrm{Ci}$. Additional characterization of the waste is needed to refine the ratio of alpha and ${ }^{90} \mathrm{Sr}$ activity to ${ }^{137} \mathrm{Cs}$ activity in order to allow more material to be buried.

\section{References}

1. Nuclear Regulatory Commission Certificate of Compliance. MMT-TN 3-82B Certificate of Compliance \#6574.

2. Safety Analysis Report for the 3-82B Radwaste Shipping Cask, STD-R-02-014, Scientific Ecology Group, Inc., Oak Ridge, TN. 1991.

3. DOT Shipping Regulations.

4. WHC-EP-0063-4. Hanford Site Solid Waste Acceptance Criteria.

5. WISE. Electric Power Research Institute, 3412 Hillview Avenue, Palo Alto, California. 1987.

6. Excel 97 SR-1. Microsoft Corporation, 1997. 
HNF-3636, Rev. 0

7. 85600-Battelle-bf222673. Characteristics of Radioisotopic Heat Sources. 1973.

8. EBU-RCAL-002. 3-82B Shipping Cask Shielding Analysis. Waste Management Northwest, 1998. 
Appendix A. Excel Spreadsheet for Use in Calculating the Average Dose Rate, ${ }^{137} \mathrm{Cs}$ Activity, ${ }^{90} \mathrm{Sr}$ Activity, and Alpha Activity in a Grouted HN-200 Liner

To use the spreadsheet, enter the Grout Container Identification Number in field B-2, enter the dose rate profile measurements in fields B-3 through E-8, and enter the weight of the grouted liner in field B-12. The results of the spreadsheet are the average dose rate (field F-10), the ${ }^{137} \mathrm{Cs}$ activity (field G-6), the ${ }^{90} \mathrm{Sr}$ activity (field G-8), and the $\mathrm{nCi} / \mathrm{g}$ of alpha activity (field $\mathrm{B}-16$ ). 
HNF-3636, Rev. 0

\begin{tabular}{|c|c|c|c|c|c|c|}
\hline \multicolumn{7}{|l|}{ ID number } \\
\hline & 0 degrees & 90 degrees & 180 degrees & 270 degrees & $\begin{array}{l}\text { Average } \\
(\operatorname{Rad} / \mathrm{h})\end{array}$ & \\
\hline Dose (rad/h) & 50 & 40 & 40 & 40 & 42.5 & $1 \mathrm{CiCs}=0.219 \mathrm{rad}$ \\
\hline Dose (rad/h) & 40 & 40 & 40 & 30 & 37.5 & \\
\hline Dose $(\mathrm{rad} / \mathrm{h})$ & 50 & 120 & 20 & 30 & 55 & Cs Activity (Ci) \\
\hline Dose $(\mathrm{rad} / \mathrm{h})$ & 40 & 70 & 40 & 30 & 45 & 306 \\
\hline Dose (rad/h) & 50 & 400 & 30 & 40 & 130 & Sr Activity (Ci) \\
\hline Dose (rad/h) & 60 & 100 & 60 & 150 & 92.5 & 787 \\
\hline $\begin{array}{l}\text { Average Dose } \\
\text { Rate }(\mathrm{rad} / \mathrm{h})\end{array}$ & 48 & 128 & 38 & 53 & 67.1 & \\
\hline $\begin{array}{l}\text { Weight of Waste } \\
\text { (lb) }\end{array}$ & 5700 & & & . & & \\
\hline $\begin{array}{l}\text { Weight of Waste } \\
(\mathrm{kg}) \\
\text { alpha/Cs }\end{array}$ & 2585 & & & & & \\
\hline Fraction & 0.000408 & & & & & . \\
\hline $\begin{array}{l}\mathrm{Ci} \text { of alpha in } \\
\text { grout container } \\
\mathrm{nCi} / \mathrm{g} \text { alpha in } \\
\text { grout container }\end{array}$ & $\begin{array}{r}0.1250 \\
48.3\end{array}$ & & & & & \\
\hline
\end{tabular}


HNF-3636, Rev. 0

Appendix B. Results of the Calculations Performed to Establish the Conversion Factors for HN-200 Grout Containers 
** WELCOME TO WISE/SIMPLE **

DEVELOPED FOR EPRI

BY BATTELLE PACIFIC NORTHWEST LABORATORIES

WRITTEN AND TESTED BY WD REECE LAST ON 15 JULY 1987

FOR THIS RUN:

NUMBER OF SHAPES IS 1

ISOTOPE LIBRARY

$1 \quad$ Cs-137

MAX BETA ENERGY $=.512$ AVE BETA ENERGY $=.157$

BETA YIELD $=.946$

$$
\begin{array}{ll}
5.000 \mathrm{E}-03 & 1.040 \mathrm{E}-02 \\
3.200 \mathrm{E}-02 & 2.070 \mathrm{E}-02 \\
3.200 \mathrm{E}-02 & 3.820 \mathrm{E}-02 \\
3.600 \mathrm{E}-02 & 1.390 \mathrm{E}-02 \\
6.620 \mathrm{E}-01 & 8.998 \mathrm{E}-01
\end{array}
$$

\section{SHIELDING MATERIALS LIBRARY}

FOR MATERIAL 1 --grout

ATOMIC NUMBER (Z) IS $1.000 \mathrm{E}+01$

FOR ENERGY (IN MEV)

$\begin{array}{lllllll}.200 & 300 & 400.500 & 600 & 8001.0001 .5002 .0003 .0004 .0006 .000\end{array}$

MU (IN CM(-1)) IS

$\begin{array}{lllllllllll}.203 & .173 .154 .141 & .130 & .114 & .102 & .083 & .072 & .058 & .051 & .043\end{array}$

FOR MATERIAL 2 --steel

ATOMIC NUMBER (Z) IS $2.600 \mathrm{E}+01$

FOR ENERGY (IN MEV)

$\begin{array}{llllll}.200 .300 .400 .500 .600 & 8001.0001 .5002 .0003 .0004 .0006 .000\end{array}$

MU (IN CM(-1)) IS

$\begin{array}{llllllllllll}1.148 & .865 & .739 & .660 & .605 & .527 & .472 & .385 & .338 & .283 & .259 & .244\end{array}$

SOURCE LIBRARY

SOURCE KEY 1 
FOR Cs-137 THE CONCENTRATION $=$ 7.190E-01 (MICROCURIES/GEOMETRIC UNIT)

\section{ESTIMATED BREMSSTRAHLUNG CONTRIBUTIONS}

BREMSTRAHLUNG SHOULD CONTRIBUTE LESS THAN 20\% TO ANY DOSE

FOR SHAPE 1 (CYLINDER)

$(\mathrm{X} 1, \mathrm{Y} 1, \mathrm{Z} 1)=.000 \mathrm{E}+00 \quad .000 \mathrm{E}+00 \quad .000 \mathrm{E}+00$

$(\mathrm{X} 2, \mathrm{Y} 2, \mathrm{Z} 2)=.000 \mathrm{E}+00 \quad .000 \mathrm{E}+00 \quad 1.320 \mathrm{E}+02$

RADIUS $=5.794 \mathrm{E}+01$

WALL THICKNESS IS $3.250 \mathrm{E}-01$

FILL MATERIAL IS grout

WALL MATERIAL IS steel SOURCE KEY IS 1.

ENTER THE COORDINATES FOR THE DOSE POINT

MEASUREMENTS ARE IN CENTIMETERS

EXAMPLE - 0.0,10.0,0.0

$\begin{array}{lll}.0000000 & 58.3000000 \quad 66.0000000\end{array}$

RESULTS FROM THIS INPUT FOLLOW

FOR SHAPE \# $\quad 1$ RESULT IS $\quad 218.9430000$

FOR THE POINT

WHOSE COORDINATES ARE... $\quad .000 \mathrm{E}+00 \quad 5.830 \mathrm{E}+01 \quad 6.600 \mathrm{E}+01$ TOT AL DOSE (MREM/HR) IS.....

$2.189 \mathrm{E}+02$

WOULD YOU LIKE ANOTHER DOSE POINT? (Y/N)

$\mathbf{n}$ 
HNF-3636, Rev. 0

Appendix C. Results of Hand Calculations and Computer Models Used to Model the HN-200

Grout Container as Six Source Slices (14 pages) 
HNF-3636, Rev. 0

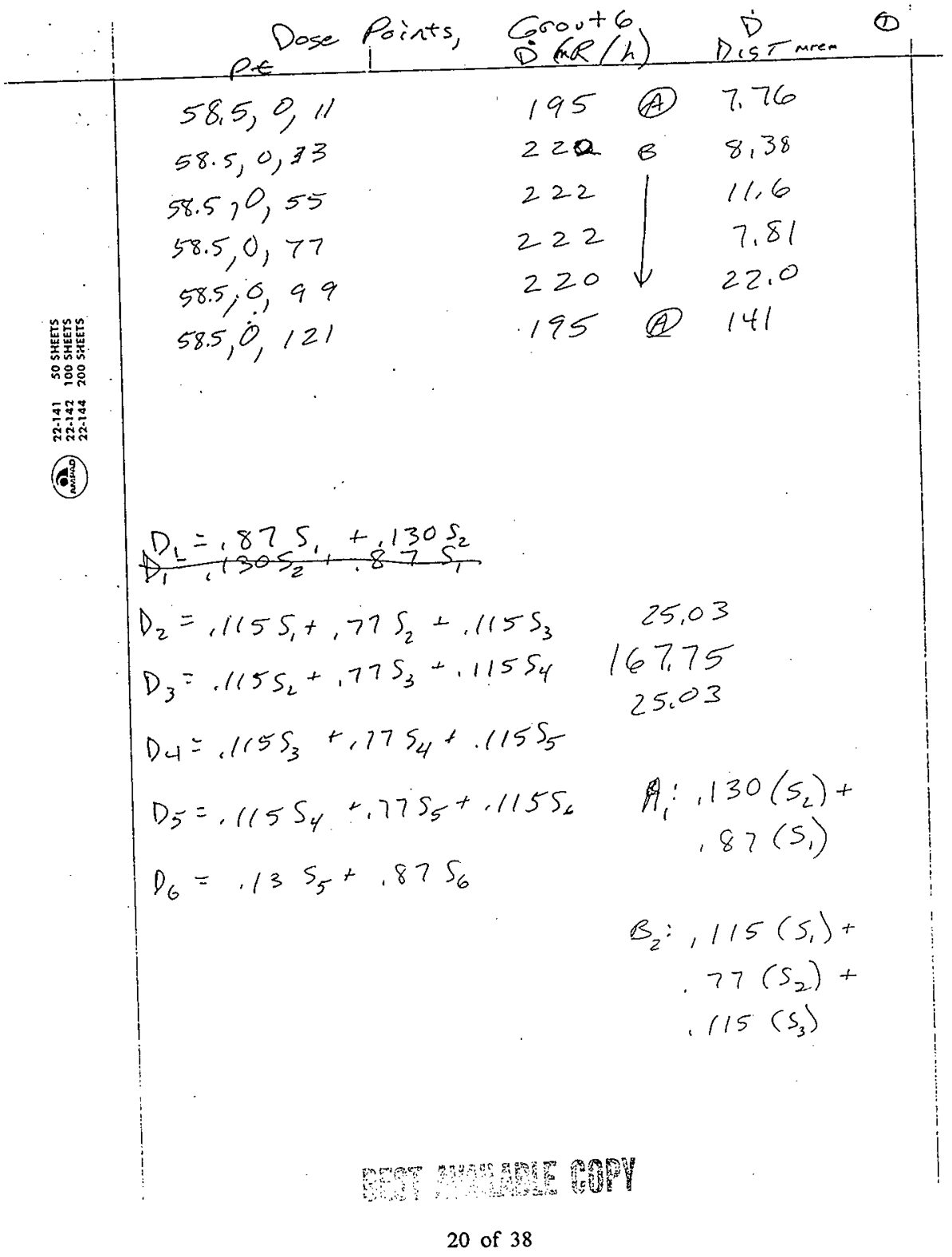


HNF-3636, Rev. 0

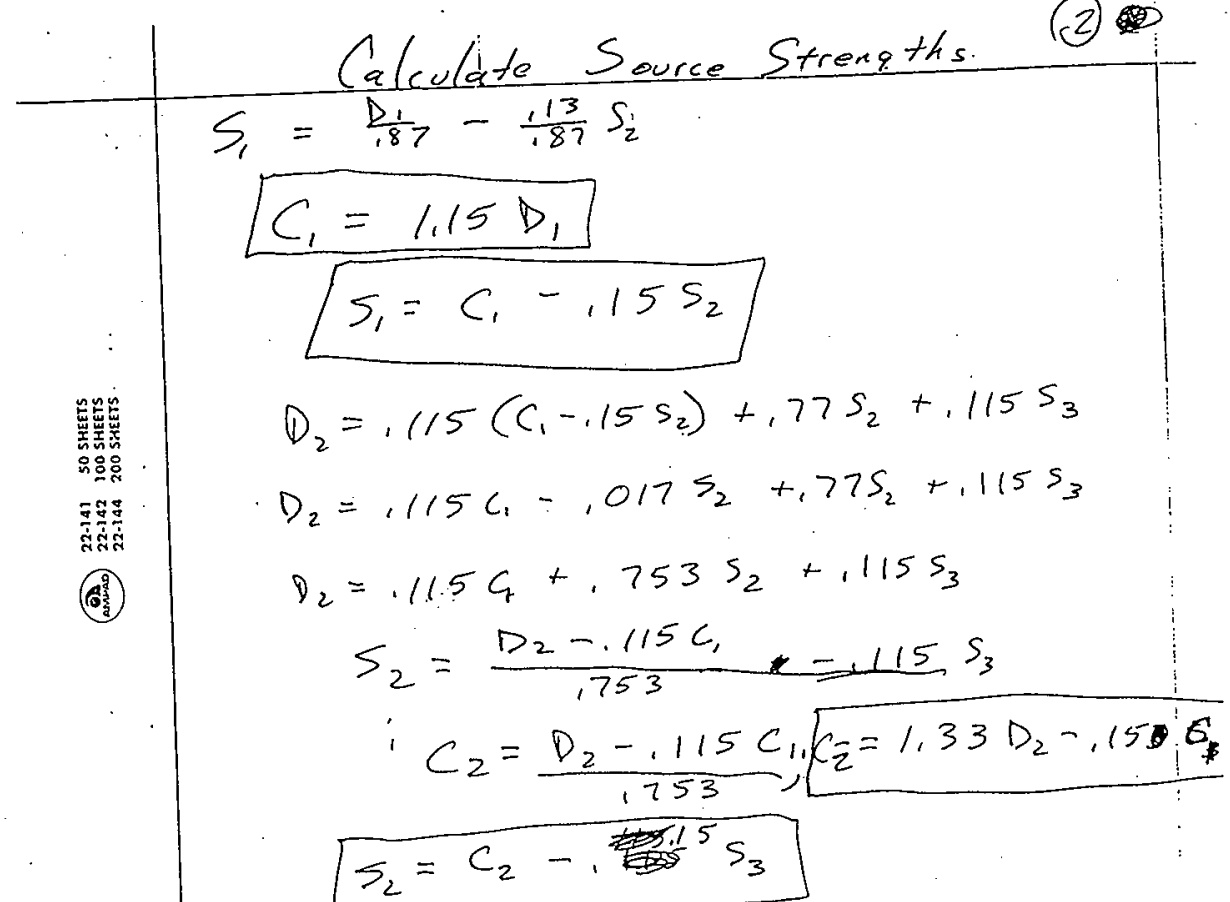

$$
\begin{aligned}
& D_{3}=.115 S_{2}+.77 S_{3}+.115 S_{4} \\
& D_{3}=115\left(C_{2}-.15 S_{3}\right)+.77 S_{3}+.115 S_{4} \\
& D_{3}=.115 C_{2}-.017 S_{3}+.77 S_{3}+.115 S_{4} \\
& D_{3}=.115 C_{2}+.75 S_{3}+.115 S_{4} \\
& S_{3}=\frac{D_{3}-.115 C_{2}-.115 S_{4}}{C_{3}=1.33 D_{3}-.15 C_{2}} \\
& \frac{S_{3}=C_{3} .15 S_{4}}{21 \text { of } 38}
\end{aligned}
$$

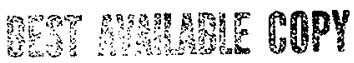


HNF-3636, Rev. 0

$$
\begin{aligned}
& \begin{array}{l|l}
D_{4}=.115 S_{3}+.77, S_{4}+.115 S_{5} \\
D_{4}=.115\left(C_{3}-.15 S_{4}\right)+.77 S_{4}+.115 S_{5} \\
D_{4}=.115 C_{3}-.017 S_{4}+.77 S_{4}+.115 S_{5} \\
S_{4}=\frac{D_{4}-.115 C_{3}-.115 S_{5}}{175}
\end{array} \\
& C_{4}=1.33 D_{4} \div .15 C_{3} \\
& S_{4}=C_{4}-.15 S_{5} \\
& D_{5}=1115 S_{4}+.77 S_{5}+.115 S_{6} \\
& D_{5}=.115\left(C_{4}-.15 S_{5}\right)+.77 S_{5}+.115 S_{6} \\
& D_{5}=.115 C_{4}-.017 S_{5}+.77 S_{4}+.115 S_{5} \\
& S_{5}=\frac{D_{5}-.115 C_{4}-.115 S_{6}}{.75} \\
& C_{5}=1.33 D_{5}-1,15 C_{4} \\
& S_{5}=C_{5}-.15 S_{5} \\
& D_{6}=.13 S_{5}+.87 S_{6} \\
& D_{6}=113\left(C_{5}-.15 S_{6}\right)+.87 S_{6} \\
& D_{6}=.13 C_{5}-.0195 S_{6}+.87 S_{6} \\
& D_{6}=.13 C_{5}+.85 S_{6} \\
& 22 \text { of } 38
\end{aligned}
$$


HNF-3636, Rev. 0

(4) (3)

$$
\begin{aligned}
& S_{6}=\frac{D_{6}-.13 C_{5}}{.85} \\
& C_{6}=1.18 D_{6} \\
& S_{6}=1.18 D_{6}-.15 C_{5}
\end{aligned}
$$

F⿱

23 of 38 
** WELCOME TO WISEISIMPLE **

DEVELOPED FOR EPRI

$\therefore \quad$ BY BATTELLE PACIFIC NORTHWEST LABORATORIES

WRITTEN AND TESTED BY WD REECE LAST ON 15 JULY 1987

FOR THIS RUN:

NUMBER OF SHAPES IS 6

ISOTOPE LIBRARY

$1 \quad \operatorname{Cs}-137$

MAX BETA ENERGY $=.512$ AVE BETA ENERGY $=.157$

BETA YIELD $=.946$

5.000E-03 1.040E-02

3.200E-02 2.070E-02

3.200E-02 3.820E-02

3.600E-02 1.390E-02

6.620E-01 8.998E-01

\section{SHIELDING MATERIALS LIBRARY}

FOR MATERIAL 1 --Steel

ATOMIC NUMBER (Z) IS $2.600 \mathrm{E}+01$

FOR ENERGY (IN MEV)

.200 .300 .400 .500 .600 .8001 .0001 .5002 .0003 .0004 .0006 .000

MU (IN CM(-1)) is

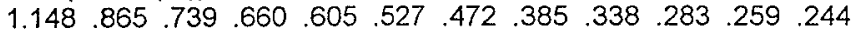

FOR MATERIAL 2 --grout

ATOMIC NUMBER (Z) IS $1.000 \mathrm{E}+01$

FOR ENERGY (IN MEV)

.200 .300 .400 .500 .600 .8001 .0001 .5002 .0003 .0004 .0006 .000

MU (IN CM(-1)) IS

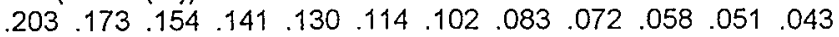

FOR MATERIAL 3 --lead

ATOMIC NUMBER (Z) IS $8.200 E+01$

FOR ENERGY (IN MEV)

$.200 \quad 300.400 \quad 500 \quad 600 \quad 8001.0001 .5002 .0003 .0004 .0006 .000$ MU (IN CM(-1)) IS

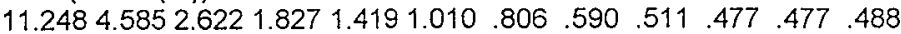

FOR MATERIAL 4 --air 
ATOMIC NUMBER (Z) IS 7.000E+00

FOR ENERGY (IN MEV)

.200 .300 .400 .500 .600 .8001 .0001 .5002 .0003 .0004 .0006 .000

MU (IN CM(-1)) IS

.000 .000 .000 .000 .000 .000 .000 .000 .000 .000 .000 .000

SOURCE LIBRARY

SOURCE KEY 1

FOR Cs-137 THE CONCENTRATION $=7.180 \mathrm{E}-01$

(MICROCURIES/GEOMETRIC UNIT)

SOURCE KEY 2

FOR Cs-137 THE CONCENTRATION $=7.180 E-01$

(MICROCURIES/GEOMETRIC UNIT)

SOURCE KEY 3

FOR CS-137 THE CONCENTRATION $=7.180 \mathrm{E}-01$ (MICROCURIES/GEOMETRIC UNIT)

SOURCE KEY 4

FOR CS-137 THE CONCENTRATION $=7.180 E-01$ (MICROCURIES/GEOMETRIC UNIT)

SOURCE KEY 5

FOR Cs-137 THE CONCENTRATION $=7.180 \mathrm{E}-01$ (MICROCURIES/GEOMETRIC UNIT)

SOURCE KEY 6

FOR CS-137 THE CONCENTRATION $=7.180 E-01$ (MICROCURIES/GEOMETRIC UNIT)

ESTIMATED BREMSSTRAHLUNG CONTRIBUTIONS

BREMSTRAHLUNG SHOULD CONTRIBUTE LESS THAN 20\% TO ANY DOSE 
FOR SHAPE 1 (CYLINDER)

$(X 1, Y 1, Z 1)=.000 E+00 \quad .000 E+00 \quad .000 E+00$

$(X 2, Y 2, Z 2)=.000 E+00 \quad .000 E+00 \quad 2.200 E+01$

RADIUS $=5.794 \mathrm{E}+01$

WALL THICKNESS IS 3.250E-01

FILL MATERIAL IS grout

WALL MATERIAL IS Steel

SOURCE KEY IS 1.

FOR SHAPE 2 (CYLINDER)

$(X 1, Y 1, Z 1)=.000 E+00 \quad .000 E+002.200 E+01$ $(X 2, Y 2, Z 2)=.000 E+00 \quad .000 E+00 \quad 4.400 E+01$

RADIUS $=5.794 \mathrm{E}+01$

WALL THICKNESS IS 3.250 E-01

FILL MATERIAL IS grout

WALL MATERIAL IS Steel

SOURCE KEY IS 2.

FOR SHAPE 3 (CYLINDER)

$\left(X_{1}, Y_{1}, Z 1\right)=.000 \mathrm{E}+00 \quad .000 \mathrm{E}+00 \quad 4.400 \mathrm{E}+01$

$(X 2, Y 2, Z 2)=.000 E+00 \quad .000 E+00 \quad 6.600 E+01$

RADIUS $=5.794 \mathrm{E}+01$

WALL. THICKNESS IS 3.250E-01

FILL MATERIAL IS grout

WALL MATERIAL IS Stee!

SOURCE KEY IS 3.

FOR SHAPE 4 (CYLINDER)

$(X 1, Y 1, Z 1)=.000 E+00 \quad .000 E+006.600 E+01$

$(X 2, Y 2, Z 2)=.000 E+00 \quad .000 E+00 \quad 8.800 E+01$

RADIUS $=5.794 \mathrm{E}+01$

WALL THICKNESS IS 3.250E-01

FILL MATERIAL IS grout

WALL MATERIAL IS Steel

SOURCE KEY IS 4.

FOR SHAPE 5 (CYLINDER)

$(X 1, Y 1, Z 1)=.000 E+00 \quad .000 E+00 \quad 8.800 E+01$

$(X 2, Y 2, Z 2)=.000 E+00 \quad .000 E+00 \quad 1.100 E+02$

RADIUS $=5.794 \mathrm{E}+01$

WALL THICKNESS IS 3.250E-01

FILL MATERIAL IS grout 
WALL MATERIAL IS Steel SOURCE KEY IS 5.

FOR SHAPE 6 (CYLINDER)

$(X 1, Y 1, Z 1)=.000 E+00 \quad .000 E+00 \quad 1.100 E+02$

$(X 2, Y 2, Z 2)=.000 E+00 \quad .000 E+00 \quad 1.320 E+02$

RADIUS $=5.794 \mathrm{E}+01$

WALL THICKNESS IS 3.250E-01

FILL MATERIAL IS grout

WALL MATERIAL IS Steel

SOURCE KEY IS 6.

ENTER THE COORDINATES FOR THE DOSE POINT MEASUREMENTS ARE IN CENTIMETERS

EXAMPLE - 0.0,10.0,0.0

$\begin{array}{lll}58.5000000 & .0000000 & 11.0000000\end{array}$

REȘULTS FROM THIS INPUT FOLLOW

FOR SHAPE \# 1 RESULT IS 167.7474000

RESULTS FROM THIS INPUT FOLLOW

FOR SHAPE \# 2 RESULT IS $\quad 25.0342000$

RESULTS FROM THIS INPUT FOLLOW

FOR SHAPE \# 3 RESULT IS $\quad 1.8639540$

RESULTS FROM THIS INPUT FOLLOW

FOR SHAPE \# $\quad 4$ RESULT IS $1.316853 E-001$

RESULTS FROM THIS INPUT FOLLOW 
FOR SHAPE \#

5 RESULT IS 9.286723E-003

RESULTS FROM THIS INPUT FOLLOW

FOR SHAPE \#

6 RESULT IS 6.294497E-004

FOR THE POINT

WHOSE COORDINATES ARE $\ldots \quad 5.850 E+01 \quad .000 E+00 \quad 1.100 E+01$

TOTAL DOSE (MREM/HR) IS.....

$1.948 \mathrm{E}+02$

WOULD YOU LIKE ANOTHER DOSE POINT? (YIN)

y

ENTER THE COORDINATES FOR THE DOSE POINT

MEASUREMENTS ARE IN CENTIMETERS

EXAMPLE - 0.0,10.0,0.0

$58.5000000 \quad .0000000 \quad 33.0000000$

RESULTS FROM THIS INPUT FOLLOW

FOR SHAPE \# $\quad 1$ RESULT IS $\quad 25.0342000$

RESULTS FROM THIS INPUT FOLLOW

FOR SHAPE \# 2 RESULT IS 167.7474000

RESULTS FROM THIS INPUT FOLLOW

FOR SHAPE \# 3 RESULT IS 25.0342000

RESULTS FROM THIS INPUT FOLLOW 
FOR SHAPE \# 4 RESULT IS 1,8639540

RESULTS FROM THIS INPUT FOLLOW

FOR SHAPE \# 5 RESULT IS 1.316853E-001

RESULTS FROM THIS INPUT FOLLOW

FOR SHAPE\# $\quad$ 6.RESULT IS $9.286723 E-003$

FOR THE POINT

WHOSE COORDINATES ARE $\ldots \quad 5.850 E+01 \quad .000 E+00 \quad 3.300 E+01$

TOTAL DOSE (MREM/HR) IS.....

$2.198 E+02$

WOULD YOU LIKE ANOTHER DOSE POINT? (YIN)

y

ENTER THE COORDINATES FOR THE DOSE POINT

MEASUREMENTS ARE IN.CENTIMETERS

EXAMPLE $-0.0,10.0,0.0$

$58.5000000 \quad .0000000 \quad 55.0000000$

RESULTS FROM THIS INPUT FOLLOW

FOR SHAPE \# 1 RESULT IS $\quad 1.8639540$

RESULTS FROM THIS INPUT FOLLOW

FOR SHAPE \# 2 RESULT IS $\quad 25.0342000$

RESULTS FROM THIS INPUT FOLLOW 
FOR SHAPE \#

3 RESULTIS $\quad 167.7474000$

RESULTS FROM THIS INPUT FOLLOW

FOR SHAPE \#

4 RESULT IS 25.0342000

RESULTS FROM THIS INPUT FOLLOW

FOR SHAPE \# $\quad 5$ RESULT IS $\quad 1.8639540$

RESULTS FROM THIS INPUT FOLLOW

FOR SHAPE \#

6 RESULT IS 1.316853E-001

FOR THE POINT

WHOSE COORDINATES ARE... 5.850E+01 . .OOOE $+00 \quad 5.500 E+01$

TOTAL DOSE (MREM/HR) IS.....

2.217E+02

WOULD YOU LIKE ANOTHER DOSE POINT? (Y/N)

y

ENTER THE COORDINATES FOR THE DOSE POINT MEASUREMENTS ARE IN CENTIMETERS

EXAMPLE - 0.0,10.0,0.0

$58.5000000 \quad .0000000 \quad 77.0000000$

RESULTS FROM THIS INPUT FOLLOW

FOR SHAPE \# 1 RESULT IS 1.316853E-001

RESULTS FROM THIS INPUT FOLLOW 
FOR SHAPE \# $\quad 2$ RESULT IS 1.8639540

RESULTS FROM THIS INPUT FOLLOW

FOR SHAPE \# 3 RESULT IS 25.0342000

RESULTS FROM THIS INPUT FOLLOW

FOR SHAPE \# 4 RESULT IS $\quad 167.7474000$

RESULTS FROM THIS INPUT FOLLOW

FOR SHAPE \# $\quad 5$ RESULT IS $\quad 25.0342000$

RESULTS FROM THIS INPUT FOLLOW

FOR SHAPE \# 6 RESULT IS $\quad 1.8639540$

FOR THE POINT

WHOSE COORDINATES ARE $\ldots \quad 5.850 E+01 \quad .000 E+00 \quad 7.700 E+01$

TOTAL DOSE (MREM/HR) IS....

$2.217 \mathrm{E}+02$

WOULD YOU LIKE ANOTHER DOSE POINT? (Y/N)

y

ENTER THE COORDINATES FOR THE DOSE POINT

MEASUREMENTS ARE IN CENTIMETERS

EXAMPLE - 0.0,10.0,0.0

$58.5000000 \quad .0000000 \quad 99.0000000$

RESULTS FROM THIS INPUT FOLLOW 
FOR SHAPE \#

1 RESULT IS $9.286723 \mathrm{E}-003$

RESULTS FROM THIS INPUT FOLLOW

FOR SHAPE \#

2 RESULT IS 1.316853E-001

RESULTS FROM THIS INPUT FOLLOW

FOR SHAPE \#

3 RESULT IS

1.8639540

RESULTS FROM THIS INPUT FOLLOW

FOR SHAPE \# 4 RESULT IS 25.0342000

RESULTS FROM THIS INPUT FOLLOW

FOR SHAPE \# 5 RESULT IS 167.7474000

RESULTS FROM THIS INPUT FOLLOW

FOR SHAPE \# 6 RESULT IS 25.0342000

FOR THE POINT

WHOSE COORDINATES ARE $\ldots \quad 5.850 E+01 \quad .000 E+00 \quad 9.900 E+01$

TOTAL DOSE (MREM/HR) IS....

2.198E+02

WOULD YOU LIKE ANOTHER DOSE POINT? (Y/N)

y

ENTER THE COORDINATES FOR THE DOSE POINT MEASUREMENTS ARE IN CENTIMETERS 


$$
\begin{array}{ll}
\text { EXAMPLE }-0.0,10.0,0.0 \\
58.5000000 & .0000000 \quad 121.0000000
\end{array}
$$

RESULTS FROM THIS INPUT FOLLOW

FOR SHAPE \# 1 RESULT IS $6.294497 E-004$

RESULTS FROM THIS INPUT FOLLOW

FOR SHAPE \# 2 RESULT IS 9.286723E-003

RESULTS FROM THIS INPUT FOLLOW

FOR SHAPE \# 3 RESULT IS $1.316853 E-001$

RESULTS FROM THIS INPUT FOLLOW

FOR SHAPE \# $\quad 4$ RESULT IS $\quad .1 .8639540$

RESULTS FROM THIS INPUT FOLLOW

FOR SHAPE \# $\quad 5$ RESULT IS $\quad 25.0342000$

RESULTS FROM THIS INPUT FOLLOW

FOR SHAPE\# 6 RESULT IS $\quad 167.7474000$

FOR THE POINT

WHOSE COORDINATES ARE... $5.850 E+01 \quad .000 E+00^{\circ} \quad 1.210 E+02$

TOTAL DOSE (MREM/HR) IS.....

$1.948 \mathrm{E}+02$ 
HNF-3636, Rev. 0

Appendix D. Analytical Counting Laboratory Data Sheets (4 pages) 
comicant acicantlet:

Hovieter:

nto

Quetoner ID

$5 x-90$

Date: $9 / 2 m \leqslant 3$

Date: $\eta / 2 q / 45$ :

$$
\text { Total gete }
$$

Foteal arpht: a. $8 \times 1-90$

$5.92 \times-5$

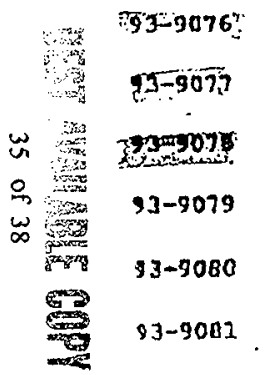

71393 " MITYE - FILSER CAR $\$ 2$

$3.658-2$

$2.35 \quad 5-1$

$7.47 \quad 5-1$

2.29

$71393 \quad 2$ WMTIE TIITHR CAN 12

$1.13 \mathrm{~B}-1$

$5.05 \mathrm{x}-2$

$2.49 \quad 8-1$

$2.22 \times-5$

21393 H HHTE EILTER CAN $\$ 2$

$7.40 x-2$

$4.37 x-2$

$1.69 \mathrm{x}-1$

$6.55 x-4$

6993 H BLACK FItTER car 11

$6.74 \dot{i}-1$

$1.35 \mathrm{E0}$

2.6650

4.BA $B-6$

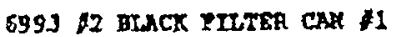

3. 89 B-2

$2.34 \mathrm{z}-2$

$9.15 \overline{5-2}$

$3.26 \quad \mathrm{H}-5$

$2.44 \mathrm{~B}-2$

$1.55 \mathrm{I}-2$

$5.92 \mathrm{E}-1$

pex your initruction, ench EItax wa lexched and the leachate analyeed. The values liated are ucl/ol of tho leach colution but no effort wae nado to pumtitute the rewulte, therefore the filtero are not dicectly comparable.

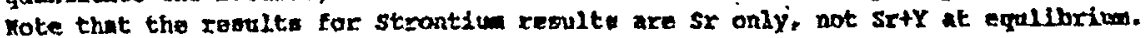


HNF-3636, Rev. 0

Battelle Pacific Northwest Laboratory

98-2812

Analytical Chemistry Laboratory.

$3 / 24 / 98$

Radioanalytical Group - 325 Bldg.

Client: S. Landsman . Wp\#: K82285

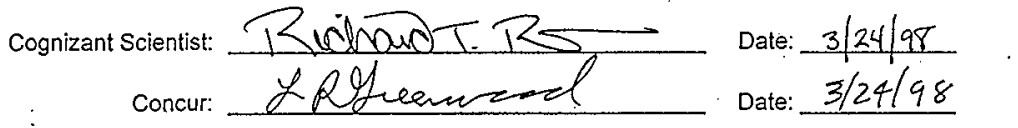

Measured Activities ( $\mu \mathrm{Ci} /$ sample)

Gamma Energy Analysis

\begin{tabular}{|c|c|c|c|c|c|c|c|c|}
\hline $\begin{array}{l}\text { ALO ID } \\
\text { Client ID }\end{array}$ & $\begin{array}{c}\text { Mn-54 } \\
\text { Error \% }\end{array}$ & $\begin{array}{c}\text { Co-60 } \\
\text { Error \% }\end{array}$ & $\begin{array}{l}\text { Sb-125 } \\
\text { Error \% }\end{array}$ & $\begin{array}{l}\text { Cs-134 } \\
\text { Error \% }\end{array}$ & $\begin{array}{l}\text { Cs-137 } \\
\text { Error \% }\end{array}$ & $\begin{array}{l}\text { Eu-154 } \\
\text { Error \% }\end{array}$ & $\begin{array}{l}\text { Eu-155 } \\
\text { Error \% }\end{array}$ & $\begin{array}{l}\text { Am-241 } \\
\text { Error \% }\end{array}$ \\
\hline $\begin{array}{l}98-2812 \\
\text { B-Cell } 1\end{array}$ & $<4 . E-5$ & $<7 . E-5$ & $<2 . E-4$ & $<3 . E-5$ & $\begin{array}{c}9.73 E-3 \\
5 \%\end{array}$ & $<1 . E-4$ & $<1 . E-4$ & $<2 . E-4$ \\
\hline $\begin{array}{l}98-2813 \\
\text { B-Cell } 2\end{array}$ & $<8 . E-5$ & $<2 . E-4$ & $<2 . E-3$ & $<6 . E-5$ & $\begin{array}{c}2.29 E-1 \\
5 \%\end{array}$ & $<3 . E-4$ & $<7 . E-4$ & $<2 . E-3$ \\
\hline $\begin{array}{l}98-2814 \\
\text { B-Cell } 3\end{array}$ & $<2 . E-3$ & $\begin{array}{c}7.66 \mathrm{E}-2 \\
5 \%\end{array}$ & $<2$.E-2 & $<3 . E-3$ & $\begin{array}{c}8.93 E+0 \\
5 \%\end{array}$ & $<4 . E-3$ & $<7 . E-3$ & $<2 . E-2$ \\
\hline
\end{tabular}


HNF-3636, Rev. 0

Battelle Pacific Northwest Laboratory

Radioanalytical Group - 325 Bldg.

Client: S. Lanosman

Wp\#: K82285

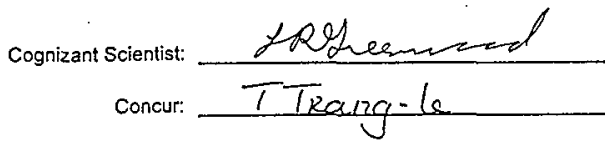

Date: $3 / 27 / 98$

Date: $3 / 29 / 98$

Measured Activities ( $\mu \mathrm{Ci} / \mathrm{sample}$ )

\begin{tabular}{lc}
$\begin{array}{l}\text { ALO ID } \\
\text { Client ID }\end{array}$ & $\begin{array}{c}\text { Sr-90 } \\
\text { Error } \%\end{array}$ \\
\hline $\begin{array}{l}98-2812 \\
\text { B-Cell } 1\end{array}$ & $1.28 \mathrm{E}-3$ \\
$5 \%$ & $5 \%$ \\
$98-2813$ & $7.69 \mathrm{E}-2$ \\
B-Cell 2 & $6 \%$ \\
$98-2814$ & $6.22 \mathrm{E}-1$ \\
B-Cell 3 & $8 \%$ \\
Standard. & $96 \%$ \\
Sample Spike & $93 \%$ \\
Blank & $<9 . E-5$
\end{tabular}


Battelle Pacific Northwest Laboratory

Radioanalytical Group - 325 Bldg.

Client: S. Landsman

Wp\#: K82285

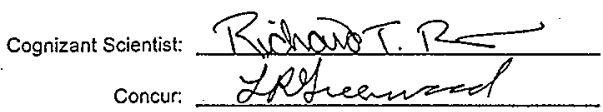

Date: $3 / 25 / 98$

Date: $3 / 25 / 98$

Measured Activities ( $\boldsymbol{\mu C i} / \mathrm{sample})$

\begin{tabular}{|c|c|c|c|c|c|c|}
\hline $\begin{array}{l}\text { ALO ID } \\
\text { Client ID }\end{array}$ & . & $\begin{array}{c}\text { Total Alpha } \\
\text { Error } \%\end{array}$ & $\begin{array}{c}\text { Pu-239/240 } \\
\text { Error \% }\end{array}$ & $\begin{array}{c}\text { Pu-238/Am-241 } \\
\text { Error } \%\end{array}$ & $\begin{array}{c}\mathrm{Cm}-243 / 244 \\
\text { Error } \%\end{array}$ & $\begin{array}{l}\text { Cm-242 } \\
\text { Error \% }\end{array}$ \\
\hline $\begin{array}{l}98-2812 \\
\text { B-Cell } 1\end{array}$ & & $\begin{array}{c}5.45 \mathrm{E}-5 \\
17 \%\end{array}$ & $<1 . E-5$ & $\begin{array}{c}4.24 \mathrm{E}-5 \\
33 \%\end{array}$ & $\begin{array}{c}1.21 E-5 \\
62 \%\end{array}$ & $<5$. E- 6 \\
\hline $\begin{array}{l}98-2813 \\
\text { B-Cell } 2\end{array}$ & & $\begin{array}{c}1.00 E-4 \\
14 \%\end{array}$ & $<2$.E-5 & $\begin{array}{c}5.88 E-5 \\
24 \%\end{array}$ & $\begin{array}{c}4.12 \mathrm{E}-5 \\
27 \%\end{array}$ & $<5 . E-6$ \\
\hline $\begin{array}{l}98-2814 \\
\text { B-Cell } 3\end{array}$ & & $\begin{array}{c}3.65 E-3 \\
4 \%\end{array}$ & $\begin{array}{c}8.00 \mathrm{E}-4 \\
7 \%\end{array}$ & $\begin{array}{c}2.28 E-3 \\
6 \%\end{array}$ & $\begin{array}{c}5.72 \mathrm{E}-4 \\
8 \%\end{array}$ & $<3 . E-5$ \\
\hline Standard & . & $101 \%$ & & & & \\
\hline Sample Spike & & $101 \%$ & & & & \\
\hline Blank & & $<2 . E-5$ & & & & \\
\hline
\end{tabular}

